\title{
Isolation and Identification of Bacillus cereus from Milk and Milk Products in Udaipur, Rajasthan, India
}

\author{
Subhash Chand Meena ${ }^{1 *}$, Abhishek Gaurav ${ }^{1}$, S.S. Shekhawat ${ }^{1}$, \\ Bincy Joseph ${ }^{2}$, Hitesh Kumar ${ }^{1}$ and Nirmal Kumar ${ }^{1}$ \\ ${ }^{1}$ Department of Veterinary Public Health, ${ }^{2}$ Department of Veterinary Microbiology, \\ College of Veterinary and Animal Science, Navania, Vallabhnagar, Udaipur, Rajasthan, India \\ *Corresponding author:
}

\section{A B S T R A C T}

\section{Keywords}

Bacillus cereus, Biochemical assay, gyrB gene, cytK gene, hblA gene

Article Info

Accepted:

24 August 2019

Available Online:

10 September 2019
The present study was envisaged with the aim to isolate and identify Bacillus cereus from milk and milk products. A total of 160 samples which comprise of raw pooled market milk $(n=20)$, pasteurized milk $(n=20)$, dahi $(n=20)$, paneer $(n=20)$, khoa $(n=20)$, milk powder $(n=20)$, ice cream $(n=20)$ and butter $(n=20)$ were collected and processed in the laboratory. Out of the 160 samples screened, Bacillus cereus could be isolated from 44 samples of different milk and milk products employing culture and biochemical assays. Also, the representative phenotypically confirmed isolates $(n=10)$ were further subjected for genotypic confirmation by using PCR. On molecular analysis, gyrB gene could be detected in $100 \%(10 / 10)$ isolates, while $60 \%(6 / 10)$ and $40 \%(4 / 10)$ of the isolates were found positive for the $c y t K$ and $h b l A$ genes, respectively. Presence of enterotoxigenic genes ( $c y t K$ and $h b l A)$ in the isolates possesses a potential health threat for the public. Keeping in the view, there is an insistent need for elaborative study with more number of samples from different part of the region.

\section{Introduction}

Bacillus cereus is a Gram positive, facultative anaerobic, spore forming, motile bacterium (Tallent et al., 2012) which is widely distributed in nature and contaminates almost every agricultural commodity (Khudor et al., 2012). The bacterium is isolated from numerous foods, including dairy products, eggs and meat (Kramer and Gilbert, 1989; Ombui et al., 2008). Bacillus cereus can grow in maximum foods at a $\mathrm{pH}$ above 4.5 and temperatures above $4^{\circ} \mathrm{C}$ (Faria-Reyes et al., 2001; Svensson et al., 2007). B. cereus associated food-borne illness occurs as two distinct intoxication syndromes; emetic and diarrhoeal (Oh et al., 2012). The diarrhoeal type of B. cereus food poisoning is caused by enterotoxins such as haemolysin BL (HBL), nonhaemolytic enterotoxin (NHE) and cytotoxin K (CytK) (Ankolekar et al., 2009, Ngamwongsatit et al., 2008).

Globally, the safety of dairy products in 
respect to food-borne diseases is a great concern. Food safety is a scientific discipline describing handling, preparation, and storage of food in ways that prevent food borne illness. It includes numerous techniques that should be followed to escape potentially severe health hazard. It is mainly true in developing countries where production of milk and several milk products prepare under unhygienic conditions and poor production practices (Tewari et al., 2012 and Kumari and Sarkar, 2014).

Rapid detection of $B$. cereus in food is important to facilitate the application of quality control measures to eradicate $B$. cereus from food and improve diagnosis of food poisoning outbreaks (Swaminathan and Feng, 1994; Rambabu and Kaiser, 2005). Best of our knowledge, studies in relation to detection of $B$. cereus in milk and milk products in Rajasthan region has not been attempted so far. Keeping this in the view the present study was envisaged to isolate and identify the $B$. cereus in the milk and milk products.

\section{Materials and Methods}

\section{Collection of samples}

A total of 160 milk and milk products samples comprising of raw pooled market milk $(n=20)$, pasteurized milk $(n=20)$, dahi $(n=20)$, paneer $(n=20)$, khoa $(n=20)$, milk powder $(n=20)$, ice-creams $(n=20)$, and butter samples $(n=20)$, were collected from dairies and sweet shops of Udaipur city, Rajasthan. The sample were collected aseptically in sterile sampling vials and transported on ice packs to the laboratory immediately.

\section{Isolation and identification}

After collection of samples, $1 \mathrm{ml} / 1 \mathrm{gm}$ of the milk and milk product sample was homogenized in $9 \mathrm{ml}$ of brain heart infusion broth and incubated at $37^{\circ} \mathrm{C}$ for 24 hours. Then a loopful of innoculum was streaked on selective medium polymyxin pyruvate egg yolk mannitolbromothymol blue agar (PEMBA) and incubated at $37^{\circ} \mathrm{C}$ for 24 hours. After 24 hours, the plates were observed for the presence of peacock blue coloured colonies. Suspected colonies were further confirmed by biochemical tests viz; colony morphology, egg yolk reaction, haemolysis pattern, motility characteristics, catalase, urease, nitrate reduction, sugar fermentation, oxidase, indole, methyl red, vogesproskauer and citrate test.

\section{Molecular characterization of Bacillus cereus}

Bacillus cereus isolates were subjected to PCR for finding out the presence of the $g y r B$ gene, cytk gene and $h b l A$ gene. The primers designed by Tewari et al., (2013) (F5'TCATGAAGAGCCTGTGTACG3'; R5'CGACGTGTCAATTCACGCGC3') were used in this study for detection of $g y r B$ gene for differentiation and confirmation of $B$. cereus. The primers used in the present study for detection of cytk gene were designed by Kwarteng et al., (2017) (F5'ACAGATATCGGGTCAAAATGC3'; R5'TCCAACCCAGTTATGCCAGTTC3'), while for $h b l A$ gene primer designed by Das et al., (2009) (F-5'GCTAATG TAGTTT CACCTGTAGCAAC3'; R- AATCATGCCA CTGCGTGGACATATAA3').

\section{Results and Discussion}

The isolation and identification results are depicted in Table 1. Out of the 160 samples screened, Bacillus cereus could be isolated from 44 samples of different milk and milk products employing culture and biochemical assays. Also, the representative phenotypically confirmed isolates $(n=10)$ 
were further subjected for genotypic confirmation by using PCR. On molecular analysis, gyrB gene could be detected in $100 \%(10 / 10)$ isolates, while $60 \%(6 / 10)$ and $40 \%$ (4/10) of the isolates were found positive for the $c y t K$ and $h b l A$ genes, respectively.

Out of 160 samples screened, the positivity of Bacillus cereus was recorded in $30 \%(6 / 20)$ raw pooled market milk, 20\% (4/20) pasteurized milk, 5\% (1/20) dahi, 25\% (5/20) paneer, $45 \%$ (9/20) khoa, 25\% (5/20) milk powder, $30 \%(6 / 20)$ ice-cream and $40 \%$ $(8 / 20)$ of butter samples.

The findings of the present study are in accordance with the earlier studies, wherein the prevalence of the Bacillus cereus in raw market milk sample was around $30 \%$ (Khudor et al., 2012; Abraha et al., 2017; Ali et al., 2016; Yusuf et al., 2018). However, higher prevalence rate were revealed in the study conducted by Kwarteng et al., (2017) and Gundogan and Avci, (2014) in which Bacillus cereus was found in $47 \%$ and $90 \%$ of raw milk samples, respectively, while a lower prevalence rate of $11 \%, 9.8 \%$ and $9.84 \%$ were also recorded for Bacillus cereus contamination in raw milk by Tewari et al., (2012), Cui et al., (2016) and Fossi et al., (2017), respectively.

Table 1 Results of isolation and identification of Bacillus cereus in milk and milk products

\begin{tabular}{|c|c|c|c|c|c|c|c|c|}
\hline Positivity & $\begin{array}{c}\text { Raw } \\
\text { milk }\end{array}$ & $\begin{array}{c}\text { Pasteurized } \\
\text { milk }\end{array}$ & Dahi & Paneer & Khoa & $\begin{array}{c}\text { Milk } \\
\text { powder }\end{array}$ & $\begin{array}{c}\text { Ice } \\
\text { cream }\end{array}$ & Butter \\
\hline Phenotypically & $30 \%(6)$ & $20 \%(4)$ & $5 \%(1)$ & $25 \%(5)$ & $45 \%(9)$ & $25 \%(5)$ & $30 \%(6)$ & $40 \%(8)$ \\
\hline GyrB gene & $100 \%$ & $100 \%$ & ND & ND & ND & ND & ND & ND \\
\hline CytK gene & $66.66 \%$ & $50 \%$ & ND & ND & ND & ND & ND & ND \\
\hline HblA gene & $50 \%$ & $25 \%$ & ND & ND & ND & ND & ND & ND \\
\hline
\end{tabular}

$* \mathrm{ND}=$ Not Done

As far as the pasteurized milk is concerned Yiber et al., (2017) reported 26\% prevalence of Bacillus cereus which was slightly higher to the prevalence observed in our study (20\%). A higher prevalence of Bacillus cereus was revealed in pasteurized milk samples as $57.14 \%, 100 \%$ and $55 \%$ by Reis et al., (2013), Chitov et al., (2008) and Kumari and Sarker (2014), respectively.

In conclusion, this study reveals high level of contamination of Bacillus cereus in milk and milk products which is sufficient to produce food poisoning. The presence of psychotropic as well as heat resistant Bacillus cereus represents a potential risk for dairy products stored under refrigeration. High level of contamination in milk products is a great public health concern. So there is a need for thorough food inspection and frequent bacteriological surveillance by food inspection agencies. Keeping in the view, there is an insistent need for elaborative study with more number of samples from different part of the region. Also, it would be necessary to educate the farmer about clean milk production practices.

\section{References}

Abraha A., Bikila T., Alemu S. and Muktar Y. (2017). Bacillus Cereus isolation and load from raw cow milk sold in Markets of Haramaya District, eastern Ethiopia. 
International Journal of Food Contamination4 (15): 1-6.

Ali K.M., Tawfeeq H.M. and Ali A.M. 2016. Molecular Amplification of nheA, cytK and $h b l C G e n e s$ for the Identification of Bacillus cereus in Milk and Dairy Products. Kurdistan Academics Journal 12 (1): 25-29.

Ankolekar C., Rahmati T. and Labbe R. G. (2009). Detection of toxigenic Bacillus cereus and Bacillus thuringiensis spores in US rice. International Journal of Food Microbiology. 128 (3): 460-466.

Arora D., Singh D., Kapoor P.K., Singh Y.,Jadhav V.J. and Kumar A. (2014). Detection of Bacillus cereus in pasteurized milk sold in local market of Hisar, Haryana.Harayana vet.53(2):154155.

Bartoszewicz M., Hansen B.M. and Swiecicka I. (2008). The members of Bacillus cereus group are commonly present contaminants of fresh and heat- treated milk. Food Microbiology25(1): 588-596.

Bauer A.W., Kirby W.M., Sherris J.C. and Truck M. (1966). Antibiotic susceptibility testing by a standardized single disk method. American Journal of Clinical Pathology45 (4): 493-496.

Bej K., Mahbubani M.H., Boyce M.J. and Atlas R.M. (1994). Detection of Salmonella spp. In oysters by PCR. Applied Environment Microbiology 60: 368-373.

Chitov T., Dispan R. and Kasinrerk W. (2008). Incidence and diarrhegenic potential of Bacillus cereus in pasteurized milk and cereal products in Thailand. Journal of Food Safety 28 (4): 467-481.

Cormican M., Moris D. and Corrbet-Feeenney G. (1998). Extended spectrumlactamase production and fluoro-quinolone resistance associated with community acquired urinary tract infection. Diagnostic Microbiology and Infectious Disease 32: 377-379.

Cui Y., Lui X., Dietrich R., Martlbauer E. and Cao J. (2016). Characterization of Bacillus cereus isolates from local dairy farm in China. FEMS MicrobiolLett.363 (12): 1-10.

Das.S.,Surendran P.K. and Thampuran N. (2009). PCR-based detection of enterotoxigenic isolates of Bacillus cereus from tropical seafood. Indian $J$ Med Res. 129: 316-320.

Faria-Reyes J. F., Cagnasso M. A., IzquierdoCorser P., D'Pool G., Urdaneta A. G. and Valero-Leal K. (2001). Antimicrobial resistance of Bacillus isolated from raw milk. Universidal-del-Zulia11(6): 479484.

Fossi B. T., Akoachere J. T. K., Nchanji G. T. and Wanji S. (2017). Occurrence, heat and antibiotic resistance profile of Bacillus cereus raw cow and processed isolated from milk in Mezam Division, Cameroon. International Journal of Dairy Technology70(1): 43-51.

Grannum P.E., Fratamico P.M., Bhunia A.K. and Smith J.L. (2005). Bacillus cereus in Food borne pathogens Microbiology and Molecular Biology, Norfolk 409-419.

Khudor M.H., Abbas B.A. and Saeed B.M.S. (2012). Molecular detection of enterotoxin (cytk) gene and antimicrobial susceptibility of Bacillus cereus isolates from milk and milk products. Bas.J.Vet.Res.11 (1): 164-173.

Kumari S. and Sarkar P.K. (2014). Prevalence and characterization of Bacillus cereus group from various market dairy products in India. Dairy Science \& Technology 94: 483-497.

Kwarteng J.O., Wuni A., Akabanda F., DebrahK..T. and Jesperse L. (2017). Prevalence, virulence factor genes and antibiotic resistance of Bacillus cereussensulato isolated from dairy farms and traditional dairy product. $B M C$ Microbiology17 (65): 1-8.

Miller G. D., Jarvis J. K. and McBean L. D. (2007). Handbook of Dairy Food and Nutrition (3rd ed.). Boca Raton, FL: CRC Press.

Ngamwongsatit P., Buasri W., Pianariyanon P., Pulsrikarn C., Ohba M., Assavanig A. and Panbangred W. (2008). Broad 
distribution of enterotoxin genes (hblCDA,nheABC, cytK, and entFM) among Bacillus thuringiensis and Bacillus cereus as shown by novel primers. Internatonal Journal of Food Microbiology. 121(3): 352-356.

Oh M. H., Ham J. S. and Cox J. M. (2012). Diversity and toxigenicity among members of the Bacillus cereus group. International Journal Food Microbiology. 152 (1-2): 1-8.

Ombui J.N., Nduhiu J.G. and Macharia J.K. (2005). Immunoassay and polymerase chain reaction techniques for detection of enterotoxigenicBacillus cereus. E. Afr. Med. J.82: 422-426.

Rambabu N. and Kaiser J. (2005). Rapid detection of food borne pathogens by using molecular techniques. Journal of medicine microbiology54: 51-54.

Reis A.L.S., Montanhini M.T.M., Bittencourt J.V.M., Destro M.T. and Bersot L.S. (2013). Gene detection and toxin production evaluation of hemolysin $\mathrm{BL}$ of Bacillus cereus isolated from milk and dairy products marketed in Brazil. Brazilian Journal of Microbiology44 (4): 1195-1198.

Svensson B., Monthan A., Guinebretiere M.-H., NguyenThe C. and Christiansson A. (2007). Toxin production potential and the detection of toxin genes among strains of the Bacillus cereus group isolated along the dairy production chain. International Dairy Journal17 (10): 1201-1208.

Swaminathan B. and Feng P. (1994). Rapid detection of food borne pathogenic bacteria. Annu Rev. Microbiol.48: 401426.
Tallent S. M., Kotewicz K. M., Strain E. A. and Bennett R. W. (2012). Efficient Isolation and Identification of Bacillus cereus Group. Journal of AOAC International. 95(2): 446-451.

Tewari A., Singh S.P. and Singh R. (2012). Prevalence of multidrug resistant Bacillus cereus in food and human stool sample in and around Pantnagar, Uttrakhand. Journal of Advance Veterinary Research 2: 252-255.

Tewari A., Singh S.P., Singh R. and Kumar R. (2013). Characterization of Bacillus cereus Isolates from Raw Milk. Journal Veterinary Public Health11 (2): 145-148.

Van Netten P., Van de Moosdijk A., Van de Hoensel P., Mossel D.A. and Perales I. (1990). Psychrotrophic strains of Bacillus cereus producing enterotoxin. $J$. Appl. Bacteriol.69: 73-79.

Yibar A., Cetinkaya F. Soyutemiz E. and Yaman G. (2017). Prevalence, Enterotoxin Production and Antibiotic Resistance of Bacillus cereus İsolated from Milk and Cheese. KafkasUniversitesiveterinerfakultesiDerg isi23 (4): 635-642.

Yusuf U., Kotwal S. K., Gupta S. and Ahmed T. (2018). Identification and antibiogram pattern of Bacillus cereus from the milk and milk products in and around Jammu region. $\quad w w w . v e t e r i n a r y w o r l d . o r g 11$ : 186- 191.

Zelalem Y. and Faye B. (2006). Handling and microbial load of cow's milk and ergo fermented milk collected from different shops and producers in central highlands of Ethiopia, Ethiopian J. Ani. Prod's. 2: 67-82.

\section{How to cite this article:}

Subhash Chand Meena, Abhishek Gaurav, S.S. Shekhawat, Bincy Joseph, Hitesh Kumar and Nirmal Kumar. 2019. Isolation and Identification of Bacillus cereus from Milk and Milk Products in Udaipur, Rajasthan, India. Int.J.Curr.Microbiol.App.Sci. 8(09): 2783-2787. doi: https://doi.org/10.20546/ijcmas.2019.809.320 